Huihua Wang, Lijuan Su, Deyong Wang*, Tianpeng Qu and Ganfeng Tu

\title{
Degradation of $\mathrm{TiB}_{2} / \mathrm{TiC}$ Composites in Liquid $\mathrm{Nd}$ and Molten $\mathrm{NdF}_{3}-\mathrm{LiF}-\mathrm{Nd}_{2} \mathrm{O}_{3}$ System
}

DOI 10.1515/htmp-2015-0124

Received May 21, 2015; accepted October 24, 2015

\begin{abstract}
The degradation of titanium diboride $\left(\mathrm{TiB}_{2}\right) /$ titanium carbide (TiC) composites in the liquid $\mathrm{Nd}$ and molten $\mathrm{NdF}_{3}-\mathrm{Nd}_{2} \mathrm{O}_{3}-\mathrm{LiF}$ salts is investigated at $1,060{ }^{\circ} \mathrm{C}$, respectively. The penetration of $\mathrm{TiB}_{2} / \mathrm{TiC}$ composites by liquid $\mathrm{Nd}$ mainly depended on the grain boundaries and residual pores, even if the coherent interface is formed between $\mathrm{TiB}_{2}$ and $\mathrm{TiC}$. The oxidation of $\mathrm{TiB}_{2}$ led to further interfacial chemistry reactions, which speeded up the degradation of $\mathrm{TiB}_{2} / \mathrm{TiC}$ composites at the initial stage in $\mathrm{NdF}_{3}-\mathrm{LiF}-\mathrm{Nd}_{2} \mathrm{O}_{3}$ system. After that, the degradation was slowed because of the formation of diffusion boundary layer, and then chemical penetration was replaced gradually by the physical penetration. The dissolved $\mathrm{Ti}$ in liquid $\mathrm{Nd}$ and $\mathrm{NdF}_{3}-\mathrm{LiF}-\mathrm{Nd}_{2} \mathrm{O}_{3}$ melts are used to evaluate the corrosion rate of $\mathrm{TiB}_{2} / \mathrm{TiC}$ composites, and the calculated values were about 0.56 and $7.8 \mathrm{~mm} /$ year, respectively. After the penetration by liquid $\mathrm{Nd}$ and $\mathrm{NdF}_{3}-\mathrm{LiF}-\mathrm{Nd}_{2} \mathrm{O}_{3}$ melts, the bending strengths of $\mathrm{TiB}_{2} /$ TiC composites decreased and the fracture mode changed from transgranular to intergranular due to the decreased grain boundary force.
\end{abstract}

Keywords: $\mathrm{TiB}_{2} / \mathrm{TiC}$ composites, grain boundary, penetration, fracture mode, corrosion rate

\section{Introduction}

Titanium diboride $\left(\mathrm{TiB}_{2}\right)$ demonstrates wide application advantages as drained and inert cathode materials in aluminum and neodymium electrolysis cells [1-4]. Despite the desirable potential of $\mathrm{TiB}_{2}$ materials, inert cathodes based on $\mathrm{TiB}_{2}$ materials have not yet been

*Corresponding author: Deyong Wang, School of Iron and Steel, Soochow University, Suzhou 215000, China,

E-mail: dywang@suda.edu.cn

Huihua Wang, Lijuan Su, Tianpeng Qu: E-mail:

qutianpeng@suda.edu.cn, School of Iron and Steel, Soochow University, Suzhou 215000, China

Ganfeng Tu, Department of Material and Metallurgy, Northeastern University, Shenyang 110004, China applied in industrial cells. The main challenge lies in the sintering difficulty of monolithic $\mathrm{TiB}_{2}$ to full density without microcracking due to its high melting point, low diffusion coefficient and anisotropic structure [5-7]. The resistance toward infiltration of liquid metals along grain boundaries is most likely dependent on the microstructure of the materials, such as the grain boundaries, the grain size and finally the porosity and the degree of microcracking. Titanium carbide (TiC) is a desirable choice for avoiding some of these problems, because it has five independent slip systems and good thermodynamic compatibility with $\mathrm{TiB}_{2}[5,8,9]$. Therefore, $\mathrm{TiB}_{2} /$ TiC composites could exhibit higher densities compared to that of monolithic $\mathrm{TiB}_{2}$, which could lead to the improved corrosion resistance of $\mathrm{TiB}_{2} / \mathrm{TiC}$ cathodes in aluminum and neodymium electrolysis cells. At present, most studies mainly focus on the preparation and mechanical properties of $\mathrm{TiB}_{2} / \mathrm{TiC}$ composites [10-14]. The application in the high-temperature electrolytic systems, especially for the degradation of $\mathrm{TiB}_{2} / \mathrm{TiC}$ composites in neodymium electrolysis cells, is rarely reported.

In this work, the degradation of $\mathrm{TiB}_{2} / \mathrm{TiC}$ composites in liquid $\mathrm{Nd}$ and molten $\mathrm{NdF}_{3}-\mathrm{LiF}-\mathrm{Nd}_{2} \mathrm{O}_{3}$ salts was investigated, involving the penetration mechanisms, the decreased mechanical properties and corrosion rates calculated according to the dissolved $\mathrm{Ti}$ in the melts. The results obtained here are highly significant for guiding the application of $\mathrm{TiB}_{2} / \mathrm{TiC}$ inert cathodes in neodymium electrolysis fields, especially for the submerged neodymium reduction cells.

\section{Experiments}

\section{Materials}

The metal neodymium (Nd, purity > 99\%) from the supplier (Baotou Lanthanide New Material Technology Co. LTD, Baotou, China) and the chemical agents $\left(\mathrm{NdF}_{3}, \mathrm{LiF}\right.$ and $\mathrm{Nd}_{2} \mathrm{O}_{3}$ ) from the supplier (Second Chemical Agent Co. LTD, Suzhou, China) are used as raw materials. In order to obtain finer grains and higher densities, $\mathrm{TiB}_{2} / \mathrm{TiC}$ composites were prepared by mechanical alloying (48 h) 
followed by pressureless sintering technique. The details, involving phase evolution, preparation process and mechanical properties of the $\mathrm{TiB}_{2} / \mathrm{TiC}$ composites, have been reported in our previous studies $[15,16]$.

\section{Exposure to the liquid neodymium and molten $\mathrm{NdF}_{3}-\mathrm{LiF}-\mathrm{Nd}_{2} \mathrm{O}_{3}$ salts}

By electrical discharge machining, the $\mathrm{TiB}_{2} / \mathrm{TiC}$ plates for tests were cut off from the bulk into pieces with dimensions of $25 \times 5 \times 5 \mathrm{~mm}^{3}$. The sample surface was ground by the SiC abrasive and then polished with 5 and $1 \mu \mathrm{m}$ diamond paste. To exclude the effect of impurities, ultrasonic cleaning in ethanol was performed prior to further testing. Due to the density difference between the $\mathrm{TiB}_{2} /$ TiC composites and liquid $\mathrm{Nd}$, special molybdenum crucible was used to carry out the hot corrosion experiments. The schematic diagram is shown in Figure 1, where the test bars were immersed in the bottom liquid $\mathrm{Nd}$ and the upper molten $\mathrm{NdF}_{3}-\mathrm{LiF}-\mathrm{Nd}_{2} \mathrm{O}_{3}$ salts $\left(\mathrm{NdF}_{3}: \mathrm{LiF}=7.5: 1\right.$, $\mathrm{Nd}_{2} \mathrm{O}_{3}$ accounted for $3 \%$ of the total mass), respectively. The test bars were held at $1,060{ }^{\circ} \mathrm{C}$ for determined intervals along with the flowing argon. After the exposure, the residual $\mathrm{Nd}$ on the surface of $\mathrm{TiB}_{2} / \mathrm{TiC}$ bars was removed first by etching in $0.5 \mathrm{~mol} \mathrm{~L}^{-1} \mathrm{HCl}$ followed by cleaning with deionized water several times. The residual salts on the surface of $\mathrm{TiB}_{2} / \mathrm{TiC}$ bars were removed by scraper blade followed by polishing with $\mathrm{SiC}$ abrasive paper. The corrosion rates of $\mathrm{TiB}_{2} / \mathrm{TiC}$ degraded in liquid $\mathrm{Nd}$ and $\mathrm{NdF}_{3}-\mathrm{LiF}-\mathrm{Nd}_{2} \mathrm{O}_{3}$ melt were estimated according to

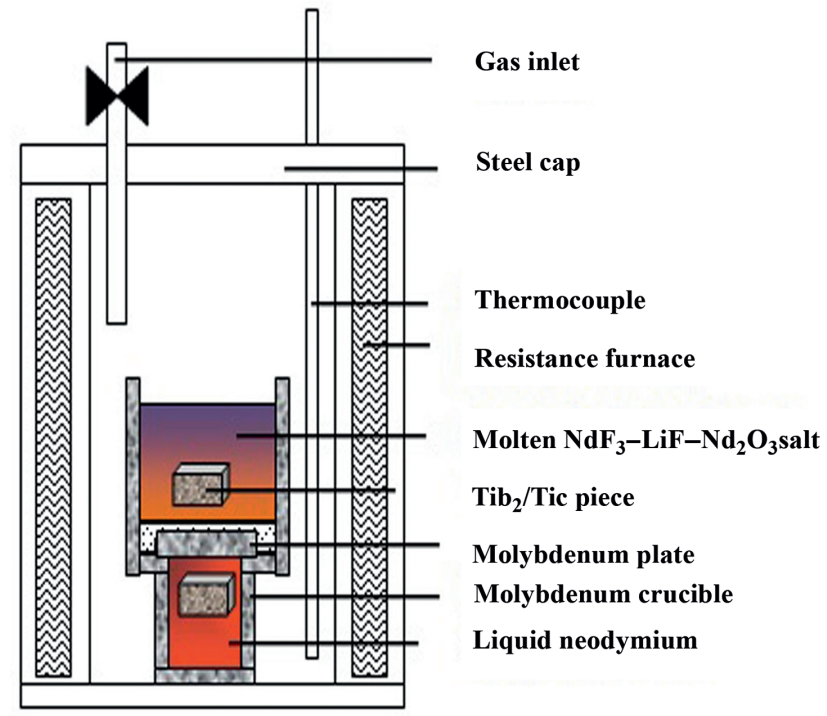

Figure 1: Schematic diagram for infiltration of melts. the dissolved $\mathrm{Ti}$ in the melts. To exclude the effect of $\mathrm{Ti}$ concentration gradients in the melts, samples were collected from top, middle and bottom portions and then mixing for inductively coupled plasma (ICP) characterization. The average corrosion rate was calculated according to the following formula:

$$
V=\frac{\Delta w}{s \times t}
$$

where $V$ is the corrosion rate $\left(\mathrm{g} / \mathrm{h} / \mathrm{cm}^{2}\right), \Delta w$ is the changing weight of $\mathrm{TiB}_{2} / \mathrm{TiC}$ composites (g), $s$ is the superficial area $\left(\mathrm{cm}^{2}\right)$ and $t$ is the exposure time (h).

\section{Characterization}

Three-point bending bars $\left(25 \times 5 \times 5 \mathrm{~mm}^{3}\right)$ were prepared according to the CTM9100 test standard. After testing, the bars were cut using an automatic cut-off machine employing a diamond blade to obtain cross sections of specimens. The cross sections were ground and polished to mirrors for further characterization. The microstructures of $\mathrm{TiB}_{2} / \mathrm{TiC}$ composites, polished cross sections and fracture surfaces of the tested bars were investigated using a Hitachi-S-4800N scanning electron microscope (SEM) attached with an energy-dispersive spectrometer (EDS). The phase component of the $\mathrm{TiB}_{2} /$ TiC composites was characterized using X-ray diffraction (XRD) (PW3040/60) with Cu-K $\alpha$ radiation by comparing the peak positions and the intensities with those from the JCPDS databases.

\section{Results and discussion}

\section{Micrographs of pristine $\mathrm{TiB}_{2} / \mathrm{TiC}$ composites}

The microstructures and phase component of the $\mathrm{TiB}_{2} / \mathrm{TiC}$ composites have been shown in Figure 2. As shown in Figure 2, the mechanical alloyed powders mainly consisted of $30-50 \mathrm{~nm} \mathrm{TiB}_{2}$ and $\mathrm{TiC}$ particles (Figure 2(a)), corresponding to the broad XRD peaks shown in Figure 2 (b). Because of the role of mechanical alloying, high activity and metastable particles were obtained, which were benefited for the subsequent sintering process. The dark elongated grains are $\mathrm{TiB}_{2}$, and the irregular but more equiaxed grains are TiC (Figure 2(c)), in agreement with the results of XRD analysis (Figure 2(d)). Sorrell et al. [17] used lattice parameter values and estimated the lattice mismatch between $\mathrm{TiB}_{2}$ and $\mathrm{TiC}$ to be only about $1.6 \%$. 

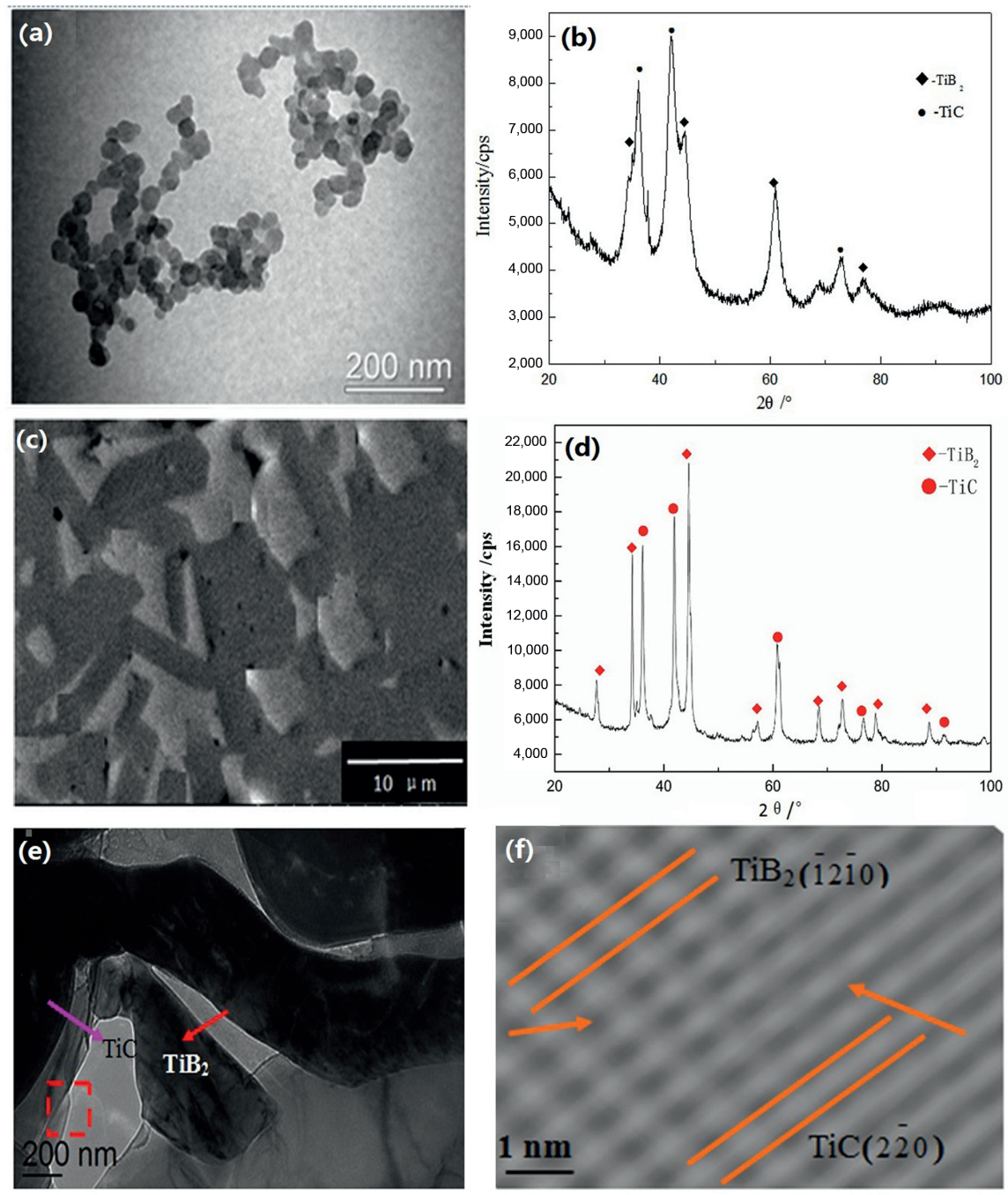

Figure 2: Images and XRD analysis of $\mathrm{TiB}_{2} / \mathrm{TiC}$ materials. (a, b) Micrographs and XRD of mechanical alloyed powders; (c, d) SEM and XRD analysis of $\mathrm{TiB}_{2} / \mathrm{TiC}$ composites; (e, f) TEM and HRTEM images between $\mathrm{TiB}_{2}$ and TiC (selected areas in the areas marked by red dash square).

Due to the good lattice match between $\mathrm{TiB}_{2}$ and $\mathrm{TiC}$, the coherent interface could be observed in dense $\mathrm{TiB}_{2} /$ TiC composites (Figure 2(e) and (f)), which led to the improved corrosion resistance properties of $\mathrm{TiB}_{2} / \mathrm{TiC}$ composites, especially for the penetration along the grain boundaries.

\section{Infiltration of liquid $\mathrm{Nd}$ and molten $\mathrm{NdF}_{3}-\mathrm{LiF}-\mathrm{Nd}_{2} \mathrm{O}_{3}$ salts in $\mathrm{TiB}_{2} / \mathrm{TiC}$ composites}

Comparing the exposed and pristine $\mathrm{TiB}_{2} / \mathrm{TiC}$ materials, the samples exposed to the liquid Nd showed mechanically soften and became more pronounced during the subsequent polishing. The samples exposed to the $\mathrm{NdF}_{3}-\mathrm{LiF}-\mathrm{Nd}_{2} \mathrm{O}_{3}$ melt exhibited the structure soften and lots of pores at the surface of the $\mathrm{TiB}_{2} / \mathrm{TiC}$ materials. Figure 3 shows the morphologies and elemental distributions of polished cross sections close to the penetration front exposed in liquid $\mathrm{Nd}$ and molten $\mathrm{NdF}_{3}-\mathrm{LiF}-$ $\mathrm{Nd}_{2} \mathrm{O}_{3}$, respectively. As shown in Figure 3(a), a thick gradient layer (about $50 \mu \mathrm{m}$ ) is formed after $48 \mathrm{~h}$ of static corrosion in the $\mathrm{NdF}_{3}-\mathrm{Nd}_{2} \mathrm{O}_{3}-\mathrm{LiF}$ system, and a small amount of melt is allowed to infiltrate slowly into the interior through the gradient layer. The interfaces were sparse and discrete compared with those in the interior of materials, suggesting the degradation of the $\mathrm{TiB}_{2} / \mathrm{TiC}$ composites during the corrosion process. A completely different phenomenon is observed when 
the $\mathrm{TiB}_{2} / \mathrm{TiC}$ composites were exposed to the liquid $\mathrm{Nd}$. The gradient layer is hardly detected around the cross section (Figure 3(b)). The element traces of $\mathrm{Nd}$ and $\mathrm{Ti}$ along the cross sections could be also observed from the EDS analysis ( Figure $3\left(a_{1}\right),\left(a_{2}\right),\left(b_{1}\right)$ and $\left(b_{2}\right)$ ), indicating the penetration sites of the melts in $\mathrm{TiB}_{2} / \mathrm{TiC}$ materials. The elemental distributions along the cross section suggested that residual pores were the main sites for the penetration of $\mathrm{TiB}_{2} / \mathrm{TiC}$ composites by liquid $\mathrm{Nd}$, because of the $\mathrm{Nd}$ energy peaks detected at the supposed locations of missing Ti energy peaks (compare Figure $3\left(b_{1}\right)$ and $\left.\left(b_{2}\right)\right)$. Comparing the energy peaks of $\mathrm{Nd}$ obtained in molten $\mathrm{NdF}_{3}-\mathrm{LiF}-\mathrm{Nd}_{2} \mathrm{O}_{3}$ melts and that in liquid Nd (Figure $3\left(a_{2}\right)$ and $\left(b_{2}\right)$ ), more Nd traces were
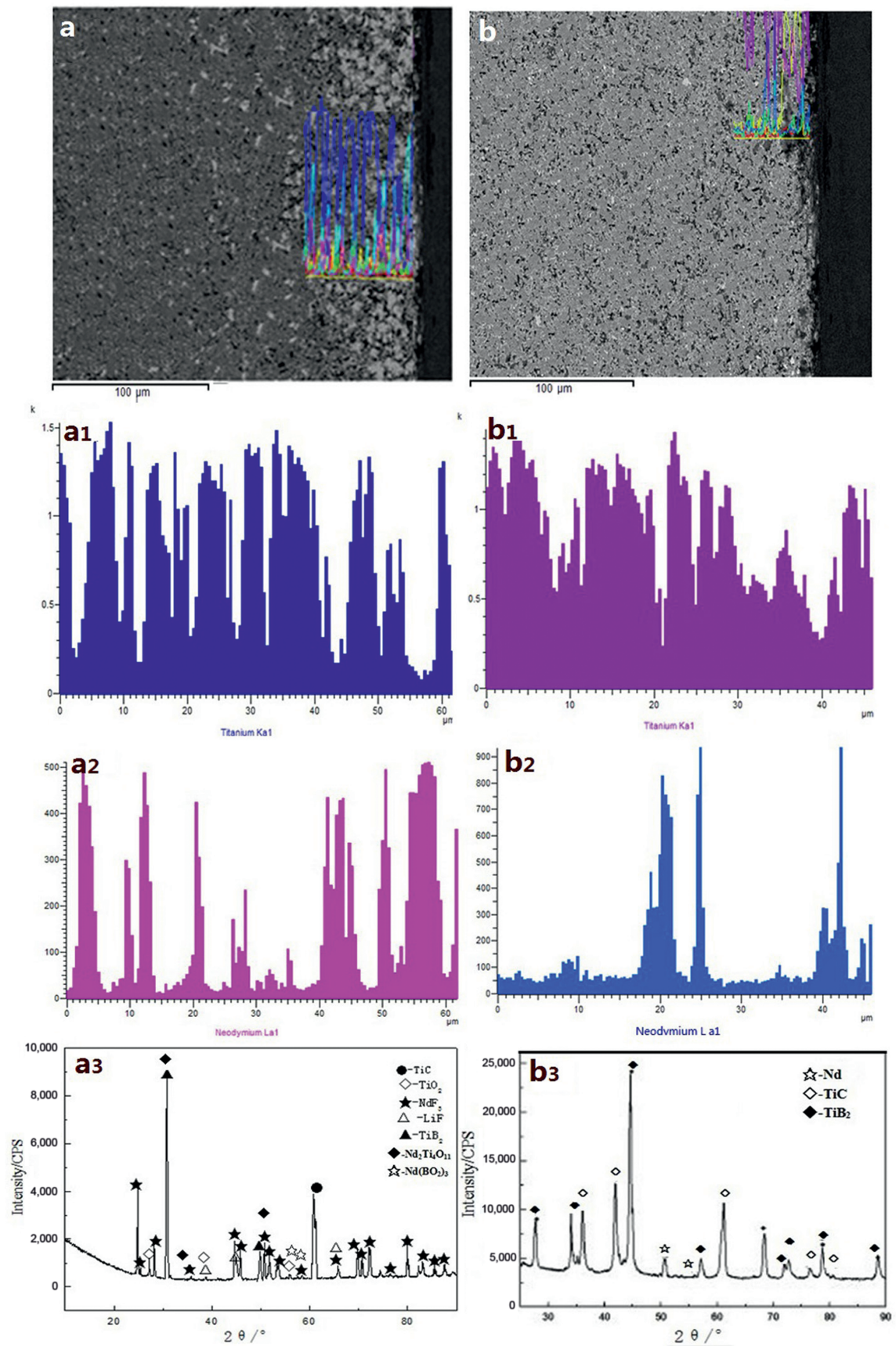

Figure 3: Micrographs and EDS analysis of the cross sections close to the penetration front of the $\mathrm{TiB}_{2} / \mathrm{TiC}$ composites exposed to (a) molten $\mathrm{NdF}_{3}-\mathrm{Nd}_{2} \mathrm{O}_{3}$ - LiF salts and (b) liquid $\mathrm{Nd}$; as well as the element distributions $\left(\mathrm{a}_{1}, \mathrm{a}_{2}\right)$ corresponding to molten $\mathrm{NdF}_{3}-\mathrm{Nd}_{2} \mathrm{O}_{3}-\mathrm{LiF}$ salts and $\left(b_{1}, b_{2}\right)$ corresponding to liquid $N d\left(a_{3}, b_{3}\right)$ showing the XRD results of the corresponding cross sections after penetration. 
detected in molten $\mathrm{NdF}_{3}-\mathrm{LiF}-\mathrm{Nd}_{2} \mathrm{O}_{3}$ melts, indicating that the penetration mechanism of $\mathrm{TiB}_{2} / \mathrm{TiC}$ composites by molten $\mathrm{NdF}_{3}-\mathrm{LiF}-\mathrm{Nd}_{2} \mathrm{O}_{3}$ melts was different from that by liquid $\mathrm{Nd}$. The penetration can cause a weakening of the grain boundary cohesion and possibly cracking, and then pull out of grains and failure of $\mathrm{TiB}_{2} / \mathrm{TiC}$ composites as cathodes during neodymium electrolysis. There are several possible mechanisms for explaining the infiltration of $\mathrm{Nd}$ or molten $\mathrm{NdF}_{3}-\mathrm{LiF}-\mathrm{Nd}_{2} \mathrm{O}_{3}$ melts along the grain boundaries or residual pores in polycrystalline ceramic materials. First, the resistance toward the infiltration of melts along the grain boundaries and residual pores most likely depend on the microstructure of the materials, especially the secondphase composition at the grain boundaries and final porosity. Although the observed grain boundaries between $\mathrm{TiB}_{2}$ and $\mathrm{TiC}$ are free of pores (Figure 2(c)), the residual pores and grain boundaries are inevitable because of the discrepant thermal expansion coefficient of $\mathrm{TiB}_{2}$ hexagonal structure and the lattice plane orientation between $\mathrm{TiB}_{2}$ and $\mathrm{TiC}$. Second, infiltration of the grain boundaries will result in the increase of internal stresses due to the anisotropic thermal expansion after infiltration. Lastly, penetration due to the direct or indirect reactions is also possible. If the reaction forms new phases with increased molar volume, internal stress will build up and possibly induce microcracking formation and by this way increase the corrosion rate. As shown in Figure $3\left(b_{3}\right)$, no reaction between $\mathrm{Nd}$ and $\mathrm{TiB}_{2} / \mathrm{TiC}$ composite is observed according to the results of XRD analysis. However, some new phases, such as $\mathrm{TiO}_{2}$, $\mathrm{Nd}_{2} \mathrm{Ti}_{4} \mathrm{O}_{11}$ and $\mathrm{Nd}\left(\mathrm{BO}_{2}\right)_{3}$, are detected from the cross sections of exposed samples in the molten $\mathrm{NdF}_{3}-\mathrm{LiF}-$ $\mathrm{Nd}_{2} \mathrm{O}_{3}$ melts, indicating the direct or indirect reactions occurring between the $\mathrm{TiB}_{2} / \mathrm{TiC}$ composites and the melts (Figure $3\left(a_{3}\right)$ ). Due to slight oxygen mixed in the flowing argon, $\mathrm{TiB}_{2}$ is more vulnerable to be oxidized than that of $\mathrm{TiC}$ at high temperature according to the reported literature [18], which leads to further reactions between the oxidized productions, such as $\mathrm{TiO}_{2}$, and molten $\mathrm{NdF}_{3}-\mathrm{LiF}-\mathrm{Nd}_{2} \mathrm{O}_{3}$. The possible reaction mechanisms could be deduced in the following:

$$
\begin{gathered}
2 \mathrm{TiB}_{2}+5 \mathrm{O}_{2}=2 \mathrm{TiO}_{2}+2 \mathrm{~B}_{2} \mathrm{O}_{3} \\
4 \mathrm{TiO}_{2}+\mathrm{Nd}_{2} \mathrm{O}_{3}=\mathrm{Nd}_{2} \mathrm{Ti}_{4} \mathrm{O}_{11} \\
3 \mathrm{~B}_{2} \mathrm{O}_{3}+\mathrm{Nd}_{2} \mathrm{O}_{3}=2 \mathrm{Nd}\left(\mathrm{BO}_{2}\right)_{3}
\end{gathered}
$$

Due to the penetration of liquid $\mathrm{Nd}$ and molten $\mathrm{NdF}_{3}-$ $\mathrm{LiF}-\mathrm{Nd}_{2} \mathrm{O}_{3}$, the degradation of $\mathrm{TiB}_{2} / \mathrm{TiC}$ composites is inevitable. The changes between corrosion rate and exposure time profile, corresponding to the materials exposed to the liquid $\mathrm{Nd}$ and molten $\mathrm{NdF}_{3}-\mathrm{LiF}-\mathrm{Nd}_{2} \mathrm{O}_{3}$, are shown in Figure 4. It should be noticed that the conversion between Ti content detected by ICP and $\mathrm{TiB}_{2} / \mathrm{TiC}$ composites is based on the target composition of $2 \mathrm{TiB}_{2} / \mathrm{TiC}$, and then the corrosion rate is calculated according to formula (1). The data used for calculating the corrosion rate are listed in Table 1 . A steep linear increase (to about $0.00041 \mathrm{~g} / \mathrm{cm}^{2} / \mathrm{h}$ ) is observed and deems to be related to the rapidly dissolved $\mathrm{TiB}_{2} / \mathrm{TiC}$ composites in molten $\mathrm{NdF}_{3}-\mathrm{LiF}-\mathrm{Nd}_{2} \mathrm{O}_{3}$ salts when the exposure time is only up to $12 \mathrm{~h}$. Afterward, the increase becomes less significant and even descends sharply between 24 and $48 \mathrm{~h}$, confirming that the chemical penetration is replaced gradually by the physical penetration when the diffusion gradient layer is formed after some time. Similar results are also observed for the infiltration of liquid $\mathrm{Nd}$.

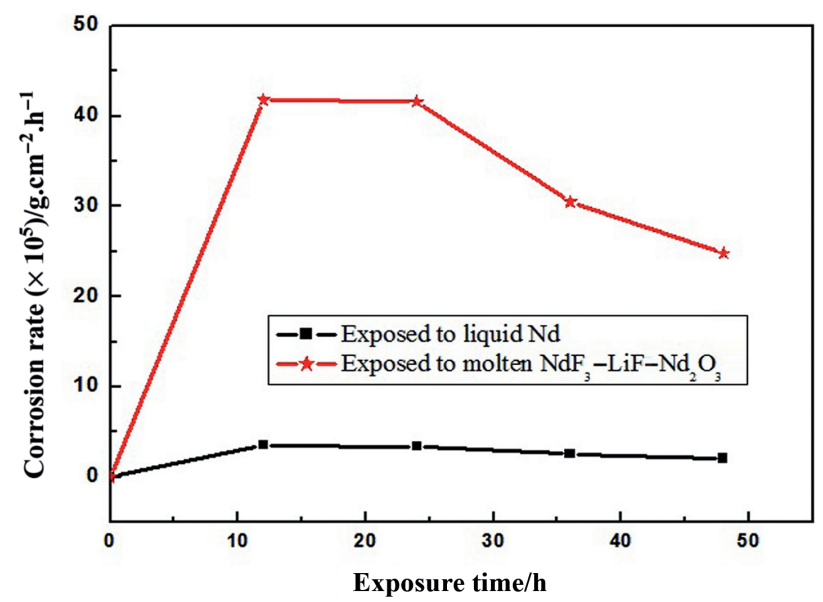

Figure 4: Relation between corrosion rate and exposure time for $\mathrm{TiB}_{2} / \mathrm{TiC}$ composites.

Table 1: Data used for calculating the corrosion rate.

\begin{tabular}{lrrrrr}
\hline $\begin{array}{l}\text { Corrosion } \\
\text { media }\end{array}$ & $\begin{array}{r}\text { Melt } \\
\text { weight/g }\end{array}$ & $\begin{array}{r}\text { Corrosion } \\
\text { area/cm }\end{array}$ & $\begin{array}{r}\text { Corrosion } \\
\text { time/h }\end{array}$ & $\begin{array}{r}\mathrm{Ti} \\
\text { content/ } \\
\text { wt \% }\end{array}$ & $\begin{array}{r}\text { Weight } \\
\text { of } 2 \mathrm{TiB}_{2} / \\
\mathrm{TiC} / \mathbf{g}\end{array}$ \\
\hline $\mathrm{Nd}$ & \multirow{2}{*}{100} & 5.5 & 12 & 0.0017 & 0.0024 \\
& & & 24 & 0.0033 & 0.0048 \\
& & & 36 & 0.0038 & 0.0051 \\
& & & 48 & 0.0041 & 0.0055 \\
$\mathrm{NdF}_{3}-\mathrm{Nd}_{2} \mathrm{O}_{3}-\mathrm{LiF}$ & \multirow{2}{*}{100} & 5.5 & 12 & 0.02 & 0.028 \\
& & & 24 & 0.041 & 0.055 \\
& & & 36 & 0.044 & 0.061 \\
& & & 48 & 0.048 & 0.065 \\
\hline
\end{tabular}


Notably, due to the oxidation reactions of $\mathrm{TiB}_{2} / \mathrm{TiC}$ composites and further reactions between the melts and intermediates, the corrosion rate of $\mathrm{TiB}_{2} / \mathrm{TiC}$ composites in $\mathrm{NdF}_{3}-\mathrm{LiF}-\mathrm{Nd}_{2} \mathrm{O}_{3}$ melts is higher than that in liquid $\mathrm{Nd}$, which is less than $0.00003 \mathrm{~g} / \mathrm{cm}^{2} / \mathrm{h}$. It is also of great importance to understand that the corrosion rate obtained in the present investigation fluctuates with prolonged exposure time. With prolonged time, the diffusion boundary layer becomes increasingly thicker, which can impede or delay the further infiltration of melts along the grain boundaries and open porosities in $\mathrm{TiB}_{2} / \mathrm{TiC}$ composites. Therefore, the corrosion rate obtained in this study is higher than that produced in actual industrial production, indicating the promising applications of $\mathrm{TiB}_{2} / \mathrm{TiC}$ composites in submerged neodymium reduction cells.

\section{Influence of the infiltration on the mechanical properties}

As shown in Figure 5, the test bars show the gradually decreased bending strengths with prolonged exposure time. Comparing the bending strengths of test bars penetrated by liquid $\mathrm{Nd}$ and those penetrated by $\mathrm{NdF}_{3}-$ $\mathrm{Nd}_{2} \mathrm{O}_{3}-\mathrm{LiF}$ melts, the descended range detected in liquid $\mathrm{Nd}$ are, however, not so pronounced probably due to a crack-bridging effect of the ductile Nd located at the grain boundaries and open porosities. Figure 6 shows the fracture morphologies of the pristine materials and those of

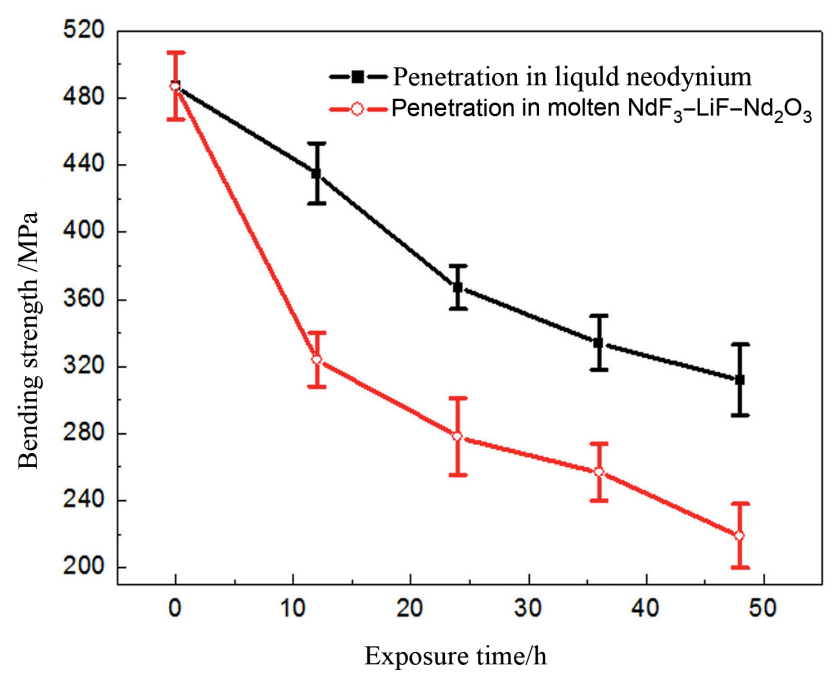

Figure 5: Bending strength as a function of exposure time for $\mathrm{TiB}_{2} / \mathrm{TiC}$ composites. penetrated materials. The grain boundary cohesion is weakened because of the infiltration of melts, which resulted in a change of fracture mode. As shown in Figure 6, the fracture mode changes from mainly intragranular to intergranular due to the soften grain boundaries and induced microcracking (compare Figure 6(a), (b) and (c)). Similar results have also been reported in the literature $[19,20]$.

\section{Potential for inert cathodes based on $\mathrm{TiB}_{2} / \mathrm{TiC}$ composites}

According to the dissolved Ti in liquid $\mathrm{Nd}$ and molten $\mathrm{NdF}_{3}-$ $\mathrm{Nd}_{2} \mathrm{O}_{3}-\mathrm{LiF}$ melts, the estimated corrosion rates are about 0.56 and $7.8 \mathrm{~mm} /$ year, respectively. The values obtained here is a little higher than that reported by Thonstad, who estimated a wear rate of $\sim 0.2 \mathrm{~mm} /$ year for a commercial Al electrolysis cell [21]. However, the results obtained here are more instructional for developing the submerged neodymium electrolysis cell equipped with the $\mathrm{TiB}_{2} / \mathrm{TiC}$ cathodes, where the $\mathrm{TiB}_{2} / \mathrm{TiC}$ cathodes are mainly corroded by the liquid Nd. Furthermore, in order to improve the corrosion resistance of $\mathrm{TiB}_{2} / \mathrm{TiC}$ composites, dense microstructures and strengthened grain boundaries between $\mathrm{TiB}_{2}$ and $\mathrm{TiC}$ are pursued in future.

\section{Conclusions}

The degradation of $\mathrm{TiB}_{2} / \mathrm{TiC}$ composites in liquid $\mathrm{Nd}$ and molten $\mathrm{NdF}_{3}-\mathrm{Nd}_{2} \mathrm{O}_{3}-\mathrm{LiF}$ salts has been investigated. Although the observed grain boundaries between $\mathrm{TiB}_{2}$ and $\mathrm{TiC}$ are free of pores, the penetration of liquid $\mathrm{Nd}$ and $\mathrm{NdF}_{3}-\mathrm{Nd}_{2} \mathrm{O}_{3}-\mathrm{LiF}$ along the grain boundaries and residual pores is evitable. Interfacial chemistry reactions occurring in $\mathrm{NdF}_{3}-\mathrm{Nd}_{2} \mathrm{O}_{3}-\mathrm{LiF}$ system led to the fast penetration by melts and high corrosion rates of $\mathrm{TiB}_{2} /$ TiC composites. However, the penetration is slowed because of the formation of diffusion boundary layer with prolonged exposure time, and then the chemical penetration is replaced gradually by the physical penetration. The dissolved $\mathrm{Ti}$ in liquid $\mathrm{Nd}$ and $\mathrm{NdF}_{3}-\mathrm{Nd}_{2} \mathrm{O}_{3}-$ $\mathrm{LiF}$ are used to estimate the corrosion rates of $\mathrm{TiB}_{2} / \mathrm{TiC}$ composites, and the calculated values were about 0.56 and $7.8 \mathrm{~mm} /$ year, respectively. After the penetration of liquid $\mathrm{Nd}$ and $\mathrm{NdF}_{3}-\mathrm{Nd}_{2} \mathrm{O}_{3}-\mathrm{LiF}$, the bending strengths of $\mathrm{TiB}_{2} / \mathrm{TiC}$ composites decreased with prolonged exposure time and the fracture mode changed from transgranular to intergranular. 

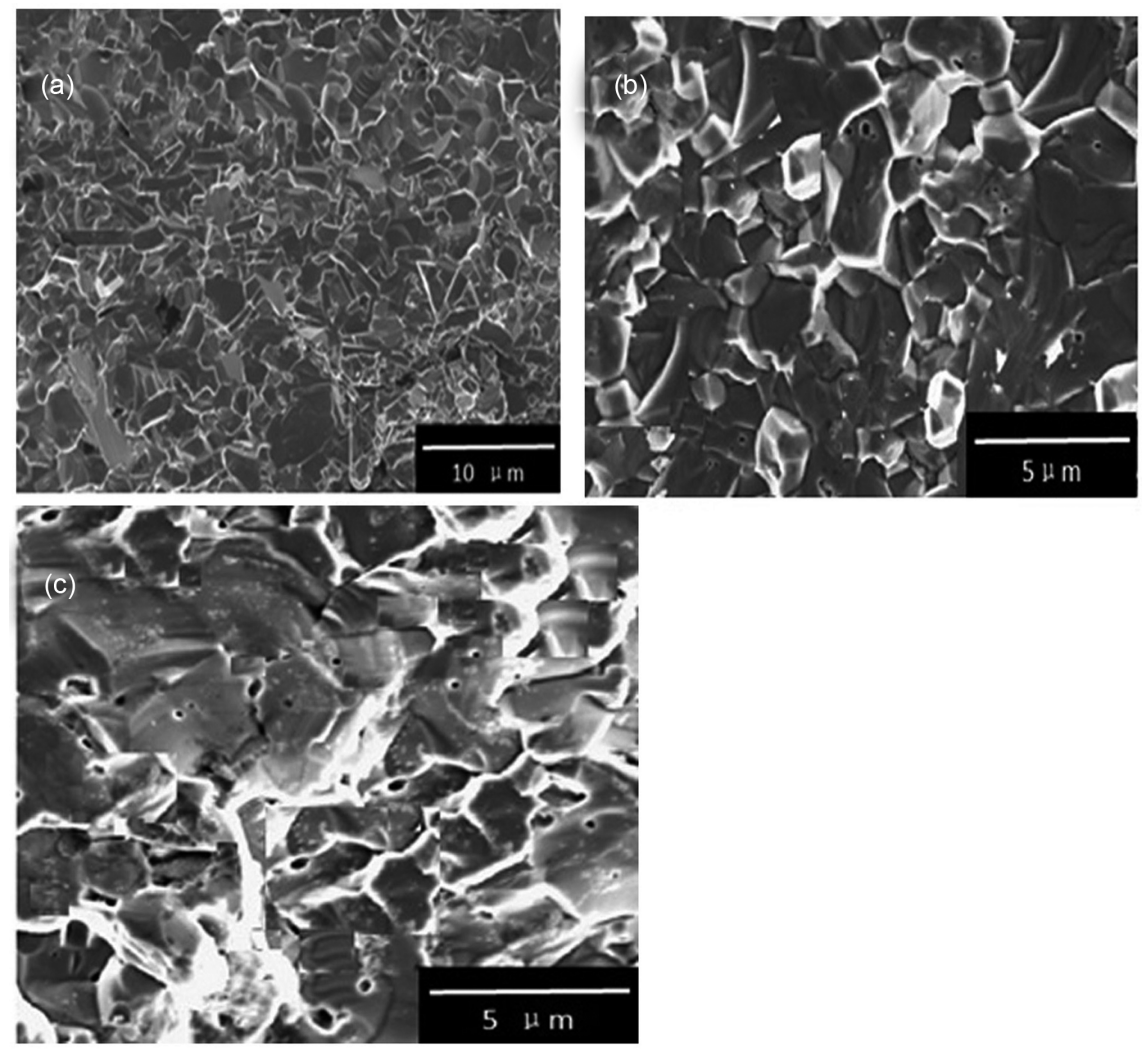

Figure 6: SEM micrographs of fracture surface for (a) pristine $\mathrm{TiB}_{2} \mathrm{TiC}$ composites, $\mathrm{TiB}_{2 /} \mathrm{TiC}$ exposed in (b) $\mathrm{Nd}$ and (c) molten $\mathrm{NdF}_{3}-\mathrm{LiF}-\mathrm{Nd}_{2} \mathrm{O}_{3}$ salts.

Funding: The authors are grateful for the financial support of the National Natural Science Foundation of China (Grant No. 51444007) and Natural Science Foundation of Jiangsu Province (Grant No. BK2014042791). Their supports enable us to complete this work.

\section{References}

[1] G. Zhang, M. Fang, and J. Qiao, Carbon Techniq., 29 (2010) 43-47.

[2] J.L. Xue, J. Zhu, B.S. Li and Q.S. Liu, Light Metal, 420 (2010) 895-900.

[3] J.L. Xue, X. Chen, Y.L. Gao and J. Zhu, Light Metals, 420 (2010) 383-386.

[4] J.J. Fei, W.M. Wang, Z.Y. Fu and H. Wang, J. Ceram., 32 (2011) 491-495.

[5] D. Vallauri, I.C. Atlas and A. Chrysanthou, J. Eur. Ceram. Soc., 28 (2008) 1697-1713.

[6] L.Y. Zheng, F.Z. Li and Y.C. Zhou, J. Am. Ceram. Soc., 95 (2012) 2028-2034.

[7] R. Lingappa, D. Canchi and J. Vikram, J. Am. Ceram. Soc., 92 (2009) 311-317.

[8] B. Ghosh and S.K. Pradhan, Mater. Chem. Phys., 120 (2010) 537-545.
[9] H.M. Ding and X.F. Liu, Trans. Nonferr. Metal. Soc., 21 (2011) 1465-1472.

[10] Z.M. Zhao, L. Zhang, Y.G. Song and W.G. Wang, Scripta Mater., 61 (2009) 281-284.

[11] Y. Wang, F.Z. Wang and H.J. Zhang, Acta Mater., 20 (2003) 22-26.

[12] A.M. Locci, O. Roberto and G. Cao, Mater. Sci. Eng. A, 434 (2006) 23-29.

[13] X.H. Zhang, C.C. Zhu and W. Qu, Compos. Sci. Technol., 62 (2002) 2037-2041.

[14] C.L. Ye, and Y.L. Chen, J. Alloy. Compd., 463 (2008) 373-377.

[15] H.H. Wang, W.Y. Wu, S.C. Sun and X. Bian, Ceram. Int., 37 (2011) 2689-2693.

[16] D.Y. Wang, H.H. Wang, S.C. Sun and G.F. Tu, Int. J. Refract. Met. H., 45 (2014) 95-101.

[17] C.C. Sorrell, H.R. Beraton, R.C. Bradt and V.S. Stubican, J. Am. Ceram. Soc., 67 (1984) 190-194.

[18] D.G. Zhu, H.L. Sun and Y.S. Wang, Adv. Mater. Res., 105 (2010) 179-183.

[19] M.S. Jensen, M. Pezzotta, Z.L. Zhang, M.A. Einarsrud and T. Grande, J. Eur. Ceram. Soc., 28 (2008) 3155-3164.

[20] O. Wouters and J. Th. M. De Hosson, Mater. Sci. Eng. A, 361 (2003) 331-337.

[21] J. Thonstad, Aluminium-Verlag, Dusseldorf (2001). 